\title{
TEACHING IN CONDITIONS OF DIFFICULT KNOWLEDGE TRANSFER DUE TO THE STATE OF EMERGENCY CAUSED BY THE PANDEMIC
}

\author{
Miloš M. Mravik ${ }^{a}$, Marko K. Šarac ${ }^{b}$, \\ Mladen $\bigoplus$. Veinovićc, Nuno G. Pombo ${ }^{d}$ \\ a Singidunum University, Belgrade, Republic of Serbia, \\ e-mail: mmravik@singidunum.ac.rs, corresponding author, \\ ORCID iD: (1)https://orcid.org/0000-0001-5442-3998 \\ b Singidunum University, Belgrade, Republic of Serbia, \\ e-mail: msarac@singidunum.ac.rs, \\ ORCID iD: (1)https://orcid.org/0000-0001-8241-2778 \\ c Singidunum University, Belgrade, Republic of Serbia, \\ e-mail: mveinovic@singidunum.ac.rs, \\ ORCID iD: (1)https://orcid.org/0000-0001-6136-1895 \\ d University of Beira Interior, Covilhã, Portugal, \\ e-mail: ngpombo@di.ubi.pt, \\ ORCID iD: (i)https://orcid.org/0000-0001-7797-8849
}

DOI: 10.5937/vojtehg69-33522; https://doi.org/10.5937/vojtehg69-33522

FIELD: Information technology

ARTICLE TYPE: Original scientific paper

\begin{abstract}
:
Introduction/purpose: This paper presents the transformation of the current, classical approach to teaching. Online platforms enable students with and without disabilities to follow classes without hindrance during the lecture period. After the lecture, they are allowed to view video and presentation materials. The main advantage of this way of teaching is the possibility of attending classes from any location and from any device; it is only important to be connected to the Internet.

Methods: Full integration with the already existing Faculty Information System has been performed. The paper describes a new approach to teaching and illustrates the expected benefits of online teaching. The platforms used in this integration are Microsoft Azure, Microsoft Office 365 Admin, Microsoft Teams, Microsoft Stream and Microsoft SharePoint.

Results: The result of the test of work with students showed that by introducing a system for online teaching, we directly affect the improvement and quality of teaching.

Conclusion: Considering all the results, it can be concluded that the transition to the online way of teaching allows end listeners a comprehensive transfer of knowledge as well as re-listening to the same.
\end{abstract}


This model can be used for an unlimited number of users in all Institutions, regardless of whether the field of activity of these Institutions is of educational origin.

Key words: education, online learning, teaching analysis, Microsoft Teams, Microsoft Azure.

\section{Introduction}

Starting from March 2020, almost all spheres of business were forced to switch to the online way of doing business. The new health crisis has demanded that more and more organizations use telecommuting to preserve and respect social and spatial distance. Therefore, the conditions created by the emergence of the Covid-19 pandemic provide an opportunity for intensive research into teleworking, all for the purpose of adapting to this way of everyday work as well as maintaining the current global economy. This way of working leads to the flexibility of employees in various types of business and provides a completely new way of working for the end users of the system. Switching to this way of working has increased productivity, reduced the costs of employers as well as employee fatigue due to daily commuting (Purcarea \& Purcarea, 2008). Certainly, the biggest problem in terms of this way of working is reflected in the adaptation to new technologies as well as raising awareness of the necessary computer knowledge of the end users of the system.

This paper describes all parts of the system that are analyzed for the purposes of teaching at university academic studies. Also, the implementation process as well as the student and faculty approach to the platform will be described.

Compared to classical teaching, online teaching offers many more benefits for students. Certainly, the biggest advantage of online teaching is the re-viewing of recorded materials as well as access to the platform from any location and any device that has Internet access.

Pokorni states in his work that in the middle of the nineties, a new term, modern distributed learning, was created. This type of distance learning is a system and process of connecting students with distributed educational resources. Distance education in relation to the classical way of education shows advantages such as enabling lifelong learning and professional development, participation in the highest quality and most prestigious programs, choosing one's way of learning as well as many others (Pokorni, 2009).

The paper combines a practical analysis of teams as a computersupported collaborative learning process (CSCL) and explains what 
teams can offer to teachers in higher education institutions. This paper argues that the online learning process develops shared learning as a process of peer interaction that the mentor mediates and structures. The discussion can be promoted by presenting certain concepts, problems or scenarios, and is led by efficiently directed questions, introduction and clarification of concepts and information and references to previously learned material (Bozkurt, 2019a), (Bozkurt, 2019b), (Bozkurt et al, 2019), (Bozkurt \& Sharma, 2020).

\section{Existing solutions}

There are a number of software solutions for online video calls on the market. This part of the area gained its greatest popularity with the appearance of the Covid-19 global pandemic. Software platforms such as Microsoft Teams, Zoom, Google Meet, Cisco Webex and many others have shifted much of their revenue to developing additional plug-ins to upgrade their existing software solutions. In this way, each company tries to position itself as a market leader and maintain its popularity with end users.

Among the large number of platforms for online video chats, the Microsoft Teams platform stood out the most. In addition to using video calls, the platform offers the possibility of using chat messages, video recording of meetings as well as creating tests directly within the platform.

Tsai predicts that by the end of 2021, Microsoft Teams will be in use in more than $41 \%$ of companies worldwide (Tsai, 2018). The current situation is such that the Microsoft Teams platform is used daily by more than 75 million active users. Statistically, in July 2019, the Microsoft Teams platform had 62 million active users. Based on these data, we come to the conclusion that the number of users of this platform has increased rapidly with the emergence of the Covid-19 pandemic.

Microsoft Teams offers the ability to integrate with the existing Moodle solutions. This provides an opportunity for educational institutions to synchronize Moodle courses, grades and assignments. By synchronizing these two platforms, we create a whole in which all modules are located on one platform (Martin \& Tapp, 2019).

Starting from the assumption that the realization of teaching depends on the educational system and the way of knowledge transfer, we come to the conclusion that the introduction of online teaching has badly affected the quality of teaching of educational institutions not accustomed to such work (Misha et al, 2020), (Fabiano \& Radenović, 
2020a), (Fabiano \& Radenović, 2020b), (Fabiano \& Radenović, 2020). Daisy and her expert team believe that the online way of transferring knowledge has caused a lot of damage to medical educational institutions in many ways. The greatest negative impact is visible in the area of practical knowledge and practical exercises. The problem that arises is that practical classes cannot be held on real examples in specialized laboratories. Another negative impact is that practical work in the real environment in the form of going to the hospital is not possible because a large number of hospitals have become Covid-19 hospitals and for that reason students do not have access to them (Henderson et al, 2020), (Juan, 2021). However, despite the challenges posed by the pandemic in providing health care, this type of virtual learning represents acceptable results of knowledge transfer. This way of knowledge transfer opens the possibility of expanding virtual teaching in all types of education around the world.

\section{Project description}

It is important to note that full integration with the already existing Faculty Information System has been performed. It would be good if after enrollment the student gets access to his Microsoft Office 365 account and with the help of the same access to the platform itself. Students have Microsoft Office 365 calendars in which the teaching dates in the current year are predefined, created by professors and assistants before the beginning of the semester. It is recommended that all students be able to follow the course optionally and that the system be fully open to guests of the system (guest access). In addition to classes, consultations are expected to be held through the Microsoft Teams platform.

Each team within the Microsoft Teams platform represents one subject. Each student has insight only into the teams (subjects) he / she is following in the current year. After passing the exam in the subject, the student is no longer authorized to access it. Realized lectures and exercises at the university are recorded in their entirety and are all visible to students after lectures and exercises. Students view videos using the Microsoft Stream platform.

For the needs of the analysis, the platform was implemented at several physical locations, namely Belgrade, Novi Sad and Nis. The system also supports the possibility of access for students who access from domains that are not from the Republic of Serbia. Students who access the platform in this way are guests of this system and have a restrictive overview of the content in relation to the students from the 
Republic of Serbia. Before the introduction of the state of emergency in the country, the university realized classes in the classical way with the use of amphitheaters and electronic classrooms. Each of these lectures involved the physical arrival of students at the university as well as the use of technical equipment by lecturers and students (computers, monitors, projectors, etc.). After the implementation of the Microsoft Teams platform, we directly reduce the cost of technical equipment.

The analysis of this paper required the assignment of more than 6000 students as well as 300 lecturers to different groups within the Faculty Information System as well as within the Microsoft Office 365 groups.

Students with previous computer knowledge and knowledge in the field of new technologies have created a very optimistic attitude towards the online way of knowledge transfer. Their performance and selfdirected learning were directly affected by the use of e-platforms during the Covid-19 pandemic.

\section{Proposed solution}

In order for integration to be possible, in addition to all other external factors that can potentially affect the quality of video and audio material transmission, the most important item is certainly the Internet connection. In this case, the speed of the Internet connection of the lecturer and the listener is important. Based on the performed test, the obtained results are such that the largest number of listeners and lecturers is in the range of $60-80 \%$ of the quality of the Internet connection. The results of this test are shown in Table 1.

Table 1 - System performance

Табела 1 - Успешност система

Таблица 1 - Эфрфективность системь

\begin{tabular}{|l|l|l|}
\hline Microsoft Service & $\begin{array}{l}\text { Number of achievement } \\
\text { points }\end{array}$ & $\begin{array}{l}\text { Maximum number of points } \\
(100 / 100 \%)\end{array}$ \\
\hline Exchange Online & 79 & 100 \\
\hline SharePoint Online & 53 & 100 \\
\hline Microsoft Teams & 72 & 100 \\
\hline $\begin{array}{l}\text { Quality of Internet } \\
\text { connection }\end{array}$ & $68 \%$ & $100 \%$ \\
\hline SUM & 204 & 300 \\
\hline
\end{tabular}


We will primarily rely on the use of the Exchange Online service. Based on a test done on 6107 users, the result shows that the average latency is $30 \mathrm{~ms}$. This number indicates that users have been able to use the app without interruption for the past 30 days. SharePoint gives slightly worse results for a reason. The obtained result is the result of the use of Wi-Fi connection by the end users of the system and slightly worse quality of the upload and download stream. Compared to the SharePoint platform, the Microsoft Teams platform offers much better performance for end users. The platform itself is the most commonly used compared to all Microsoft platforms within the Microsoft Office365 package. This is also visible in test results with final results such that UDP latency is $50 \mathrm{~ms}$, UDP jitter $27 \mathrm{~ms}$ and UDP packet loss $0.33 \%$. Based on the test, information was obtained that $31 \%$ of users who use the Microsoft Teams platform spend more than 10 hours each week in meetings or lectures, Table 1. In this way, we come to the fact that the attendance of online classes is much higher compared to traditional classes. The fact is that these results are influenced by the flexibility of access to teaching and the reduction of costs for students studying in non-residential cities (Burcea \& Marinescu, 2011). The obtained result is among the best in this part of Europe, taking into account the quality of the Internet in our country compared to the surrounding countries. The obtained results serve us to adjust the system and avoid possible unwanted problems in the following years of distance learning. The potential escalation of certain system problems can have a very negative impact on the overall learning system.

In addition to classic lectures and exercises, students use the 1-on-1 call option very often. One example of a 1 on 1 call is student and professor consultations. The average obtained on the basis of the test is such that $64 \%$ of conversations last more than 30 minutes. Based on this information, we gain insight into the fact that a large number of students use this option to develop projects in groups as well as mutual counseling. The amount of time spent on the platform in one week of lectures is visible in Figure 1. Based on the illustration, we can conclude that professors who teach in most cases use video and audio as well as screen sharing at the same time. This way of presenting creates a much greater interaction between students. Students are able to see some practical interactive examples in addition to listening to lectures.

Lecturers often use graphic boards during lectures in order to interact with the presented materials at the highest possible level. In addition to technology, the interaction is directly affected by the quality of knowledge transfer by the lecturer. The number of meetings organized 
on the Microsoft Teams platform in the previous 30 days is shown in Figure 2.

The amount of time spent on the platform in one week of lectures

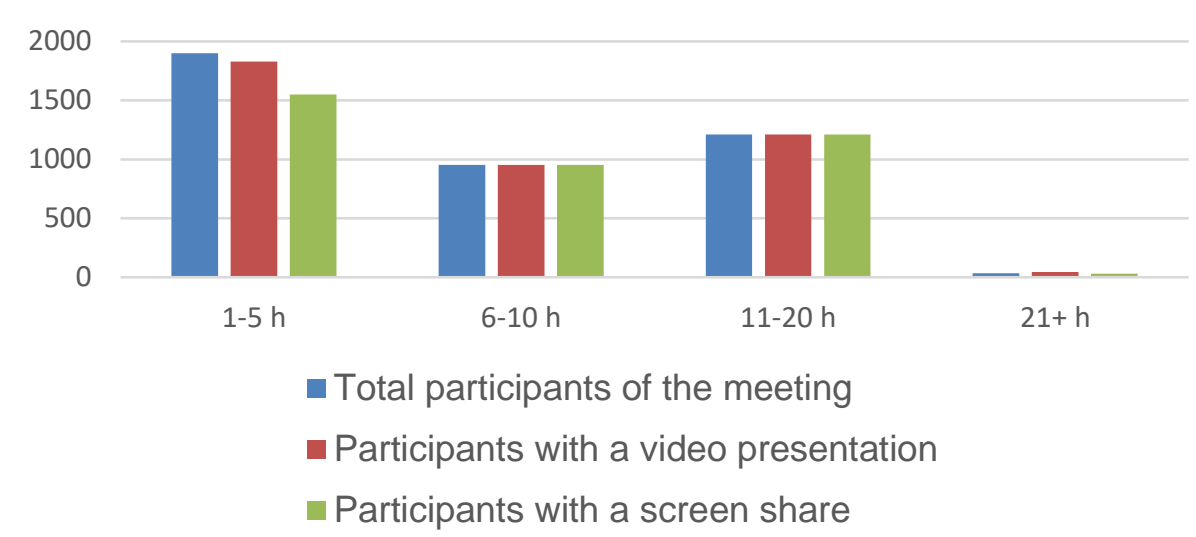

Figure 1 - The amount of time spent on the platform in one week of lectures Слика 1 - Количина проведеног времена на платформи у једној недељи предавања

Puс. 1 - Количество времени, проведенного на платформе за одну неделю лекций

Number of meetings in the previous 30 days

Instant 1: 1 meetings

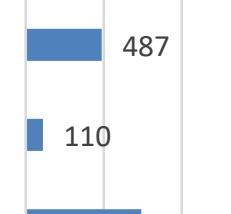

Instant "Meet now" within the channel

One-time meetings scheduled

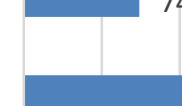

Repeated meetings scheduled

Number of meetings in the previous 30 days

Figure 2 - Number of meetings in the previous 30 days

Слика 2 - Број састанака у претходних 30 дана

Puc. 2 - Количество встреч за предыдущие 30 дней 
The use of the Microsoft Teams application has increased by $1368 \%$ since the university switched to online teaching. This is the information obtained based on the use of the previous 90 days.

Video and presentation materials can be accessed through the Files and Videos tabs on the Microsoft Teams platform. Each team / subject has an identical structure that contains the following elements:

- Posts - notifications sent to students as well as test results

- Files - page of items for storage of presentation materials

- Class Notebook - the ability to take notes by students and professors during and after lectures

- Assignments - tests created for the team / subject

- Grades - review grade students

- Video materials - view student videos using the Microsoft Stream application

Looking at the log files of the Microsoft Teams platform, we came to the conclusion that the largest number of users access the platform via computers with the Windows operating system, although a large number of system users have the ability to access via mobile phone. The time range of the graphs is 30 days. The distribution of licensed system users can be seen in Figure 3.

\section{Distribution of licensed system users}

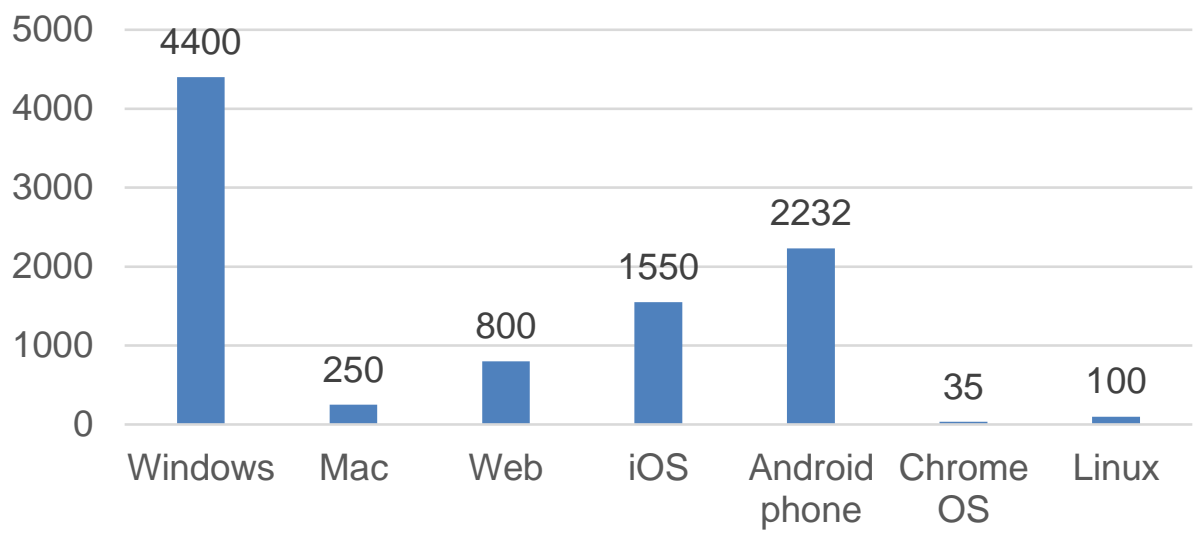

Platforms

Figure 3 - Distribution of licensed system users Слика 3 - Дистрибуција лиценцираних корисника система

Рис. 3 - Распределение лицензированных пользователей системы 
It is important to note that students are allowed access from almost all existing operating systems, which offers students additional flexibility in terms of monitoring classes (Van Rousselt, 2021).

\section{Technical presentation of the implementation of the proposed solution}

The existing infrastructure made it possible to retrieve student information from the database. The information that was needed for the successful completion of the integration is the student's e-mail and the ID of the team in which the student is. Student information is automatically read from the database and sent in .csv format to the shared disk of the existing infrastructure. For this type of integration, a PowerShell script was used, which is run using a .bat file every hour. It is primarily necessary to create new student emails using the PowerShell environment. The initial password for all University students is their JMBG number. Changing all student passwords is enabled using the PowerShell script. The first step in developing an automated proposed solution is reflected in the creation of new student Microsoft Office 365 email addresses. The PowerShell script codes are shown in the next section of the paper.

\$ErrorActionPreference $=$ "SilentlyContinue"

Stop-Transcript | out-null

\$ErrorActionPreference = "Continue"

\$LogTime = Get-Date -Format "dd-MM-yyyy HH-mm-ss"

\$LogName $=$ "Path-to-.csv-file"+\$LogTime+".txt"

Start-Transcript \$LogName

\$username $=$ "username"

\$password = ConvertTo-Securestring "password" -AsPlainText -Force

\$psCred = New-Object System.Management.Automation.PSCredential -

ArgumentList (\$username, \$password)

Connect-MsolService -Credential \$pscred

Import-CSV "Path-to-.csv-file" -delimiter “,"|Foreach-Object \{

\$userCheck = Get-MsolUser -UserPrincipalName \$_. UserPrincipalName -

ErrorAction SilentlyContinue

if (\$userCheck - ne \$Null) \{

\$userName $=\$$ _. UserPrincipalName

Write-Host "User already exists! E-mail of student is:

"\$userName

\}else\{

Write-Host "User creation begins" 


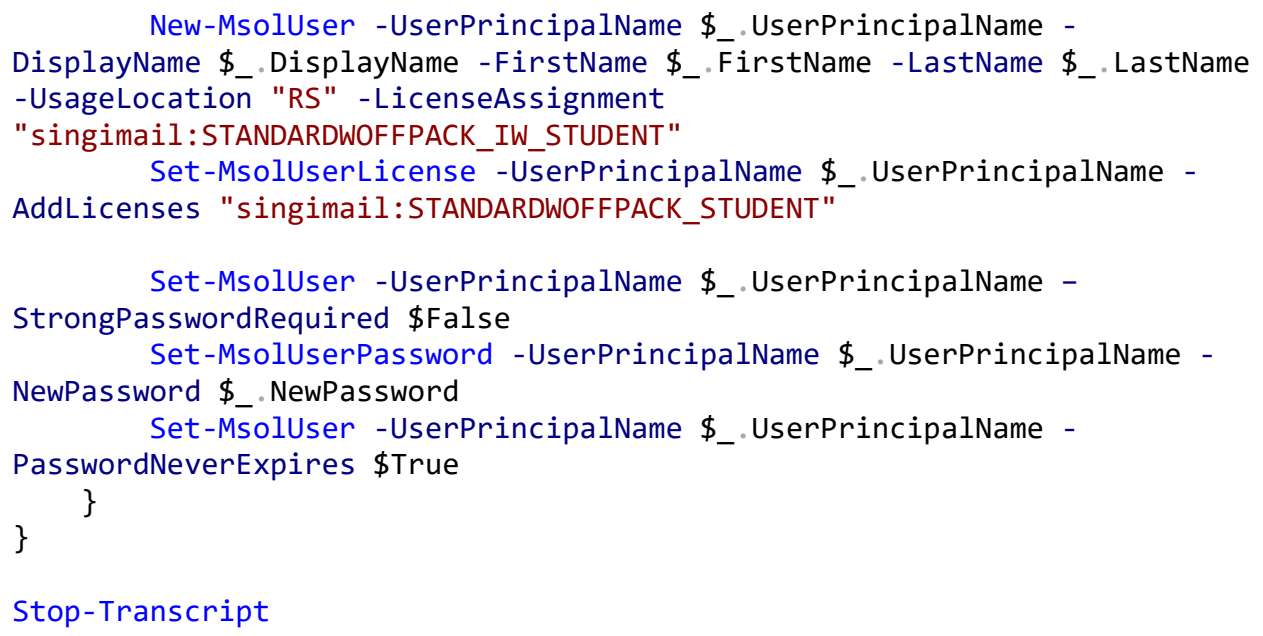

The mentioned script enabled the automation of creating emails after enrolling a student at the University. The script retrieves information from the existing Faculty Information System and creates new emails based on them. Since students will use a large number of Microsoft services, they need to be assigned the appropriate licenses. The licenses that are added to each student account are "A1 for students" and "A1 Plus for students". The assigned licenses carry all the appropriate services for uninterrupted listening to online classes. The next step defines the automation of adding students to the appropriate teams selected through the eStudent platform.

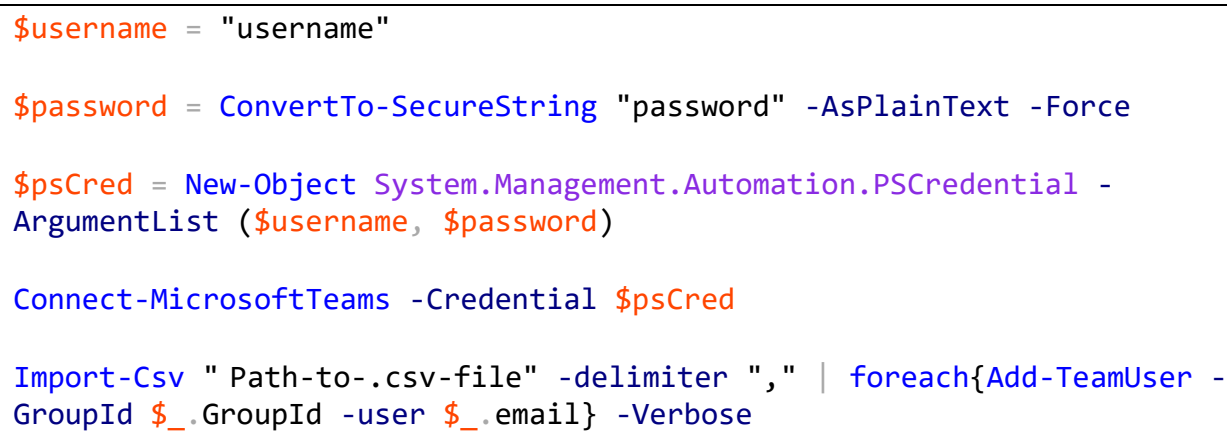

The use of the script enabled the automation of adding new students based on their email address and the ID of the team in which it is necessary to enroll a new student. 
Also, it was necessary to make a connection between the existing Faculty Information System and the Microsoft Office 365 platform. It was necessary to associate the ID numbers of all teams with all acronyms within the existing system. A link table has been created that contains this data and that greatly affects the security and execution speed of the existing scripts.

\section{Demonstration of system upgrades on the existing infrastructure}

When we look at the presence of students in online classes in relation to classical classes, we come to the conclusion that a larger number of students more regularly approached classes in online format. The statistics showing student attendance over a 30-day time range is shown in Figure 4.

\section{Number of active platform users}

\section{0}

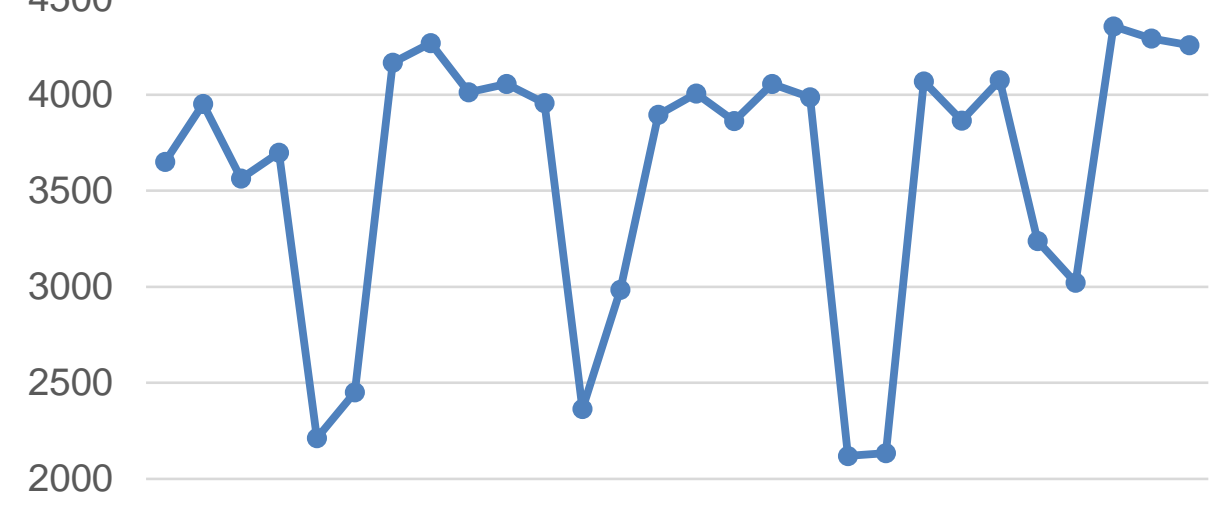

\section{$\rightarrow$ Number of students}

Figure 4-Number of active users of the platform

Слика 4 - Број активних корисника платформе

Pис. 4 - Количество активных пользователей платформы

Based on the information from the system, we can conclude that on average every day there were 3973 students who joined the Microsoft Teams platform.

The interaction of students in relation to classical teaching is much greater. The statistics showing student interaction over a 30-day time range is shown in Figure 5. The illustration shows the relationship of 
meetings held with the microphone on and the camera on. The recommendation to the lecturers is that their camera is turned on all the time while they are teaching, so that the interaction of the lecture is at the highest possible level.

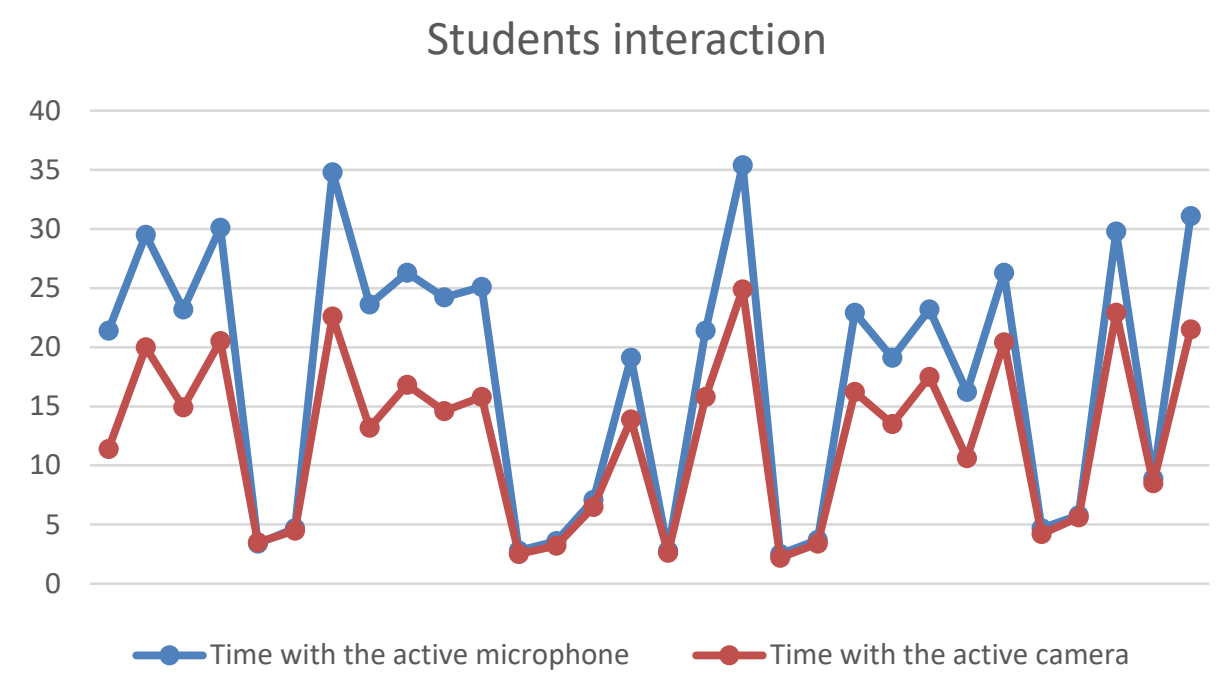

Figure 5- Student's interaction Слика 5-Интеракција студената Рис. 5- Взаимодействие студентов

The implementation of such infrastructure has greatly reduced the physical attendance at the University. Based on a test done on active students accessing the Microsoft Teams platform, the result is that $83 \%$ of students do only remote access type access while the remaining $17 \%$ are university professors, assistants and administrative staff (Jenkins, 2020). The physical presence of students is shown in Figure 6.

The possibility of remote access to services directly affects the flexibility and ease of use of the service itself. The fact that $83 \%$ of users access the service remotely tells us that the access itself is greatly facilitated. 


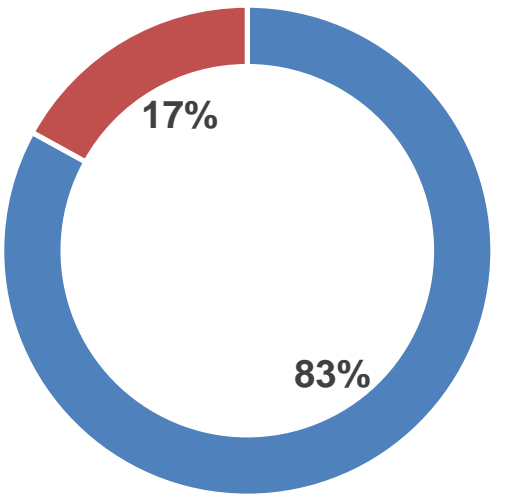

- Remote access

- Onsite access

Figure 6-Remote access and onsite access Слика 6- Удаљени приступ и онсите приступ Puc. 6 - Удаленный доступ и доступ на месте

\section{Recommendations, development plan and next steps}

According to the current situation in the country and the world, the next step in the way of teaching is still unpredictable. For now, based on testing, it is considered that the next step will be the joint implementation of classical and online teaching. The combination of these two modes of knowledge transfer is called Blended learning (Pal \& Vanijja, 2020). This way of teaching offers end listeners the opportunity to choose the format of teaching as desired, as well as the opportunity to review the recorded video materials after the lecture (Tucker, 2020).

Considering that this way of teaching is realized in one of these two ways, we come to a new concept which represents a hybrid model of teaching. This type of model offers the possibility of listening to lectures simultaneously in both classical and online ways (Tucker et al, 2016). In this case, it is up to the final listener to decide which way he wants to listen to the lecture. The hybrid model represents a synchronous type of communication while Blended learning represents an asynchronous type of communication (Cheng, 2014). Asynchronous types of communication can be used as a complement to the synchronous type of communication (Stevens, 2020). 


\section{Conclusion}

Faced with a situation that has befallen the whole world, most educational institutions have been forced to switch to online teaching. The result of the test of working with students on the Microsoft Teams platform showed that by introducing a system for online teaching, we directly affect the improvement and quality of teaching. In addition to the impact on the teaching itself, a great influence was manifested in the segment of reducing the costs of educational institutions in various fields, such as the need for amphitheaters and electronic classrooms. The basic concepts of computer network security and protocols for secure communication between professors and students are covered. The main purpose of this paper is to raise awareness of the importance of teaching online. The increase in the number of users on the Internet leads to the fact that adapting to the online type of teaching should not be a big problem of adapting to end users.

The developed model can be used on all types of educational institutions, regardless of what activities the institution is engaged in. The authors plan to conduct further qualitative research on the effectiveness of teams as a computer-supported collaborative learning (CSCL) process. There are currently very few academic studies on this mode of knowledge transfer. Continuing the development of such services and joining learning systems (Learning management system, LMS) will contribute to more significant studies that will be thrown by testing the effectiveness of these teaching processes (Bond et al, 2019).

This way of knowledge transfer represents the future and it is very important to continue research on the impact of online knowledge transfer on both the quality and the economy of all countries. It is very important to test the systems in the context of the theory of education and in this case a social constructivist approach to shared learning can be applied. A further application of this model of online learning enables a larger sample that will contribute to better analysis and a better application of distance working modes worldwide. Academics can use this information as a basic idea to improve curricula. In the future, we plan to work on a semantic analysis of the system in order to create a better system for distance learning. In the meantime, other variables that affect learning will be fully expressed and may also be added in the future to explore correlations and impacts on the learning system. Future studies may explore these models more broadly as well as the sense and degree of influence of factors that may influence the learning model 
(Archambault \& Borup, 2020), (Batty, 2020), (Dabija et al, 2014), (Dellarocas, 2003).

\section{References}

Archambault, L. \& Borup, J. 2020. Coming Together as a Research Community to Support Educators and Students in K-12 Online and Emergency Remote Settings. Journal of Online Learning Research, 6(1), pp.1-3 [online]. Available at: https://www.learntechlib.org/p/216154/ [Accessed: 28 September 2021].

Batty, D. 2020. Cambridge colleges criticized for asking students to leave over coronavirus. The Guardian, 18 March [online]. Available at: https://www.theguardian.com/education/2020/mar/18/cambridge-colleges-

criticised-for-asking-students-to-leave-over-coronavirus [Accessed: 28 September 2021].

Bond, M., Zawacki-Richter, O. \& Nichols, M. 2019. Revisiting five decades of educational technology research: A content and authorship analysis of the British Journal of Educational Technology. British Journal of Educational Technology, 50(1), pp.12-63. Available at: https://doi.org/10.1111/bjet.12730.

Bozkurt, A. 2019a. From distance education to open and distance learning: A holistic evaluation of history, definitions, and theories. In: S. Sisman-Ugur \& G. Kurubacak (Eds.). Handbook of Research on Learning in the Age of Transhumanism, pp.252-273. Hershey, PA: IGI Global. Available at: https://doi.org/10.4018/978-1-5225-8431-5.ch016.

Bozkurt, A. 2019b. Intellectual roots of distance education: a progressive knowledge domain analysis. Distance Education, 40(4), pp.497-514. Available at: https://doi.org/10.1080/01587919.2019.1681894.

Bozkurt, A., Koseoglu, S. \& Singh, L. 2019. An analysis of peer-reviewed publications on openness in education in half a century: Trends and patterns in the open hemisphere. Australasian Journal of Educational Technology, 35(4), pp.78-97. Available at: https://doi.org/10.14742/ajet.4252.

Bozkurt, A. \& Sharma, R.C. 2020. Emergency remote teaching in a time of global crisis due to CoronaVirus pandemic. Asian Journal of Distance Education, 15(1), pp.1-6. Available at: https://doi.org/10.5281/zenodo.3778083.

Burcea, M. \& Marinescu, P. 2011. Students' Perceptions on Corporate Social Responsibility at the Academic Level. Case Study: The Faculty of Administration and Business, University of Bucharest. Amfiteatru Economic, 13(29), pp.207-220 [online]. Available at: https://ideas.repec.org/a/aes/amfeco/v13y2011i29p207-220.html [Accessed: 28 September 2021].

Cheng, D. 2014. Is sharing really caring? A nuanced introduction to the peer economy. Report of the Open Society Foundation Future of Work Inquiry [online]. Available at: http://static.opensocietyfoundations.org/misc/future-ofwork/the-sharing-economy.pdf [Accessed: 28 September 2021]. 
Dabija, D-C., Postelnicu, C. \& Pop, N.A. 2014. Methodology for Assessing the Degree of Internationalization of Business Academic Study Programmes. Amfiteatru Economic, 16(37), pp.726-745 [online]. Available at: https://www.amfiteatrueconomic.ro/ArticolEN.aspx?CodArticol=1308 [Accessed: 28 September 2021].

Dellarocas, C.N. 2003. The Digitization of Word of Mouth: Promise and Challenges of Online Feedback Mechanisms. Management Science, 49(10), pp. 1275-1444. Available at: https://doi.org/10.1287/mnsc.49.10.1407.17308.

Fabiano, N. \& Radenović, S.N. 2020a. On COVID-19 diffusion in Italy: data anal-ysis and possible outcome. Vojnotehnički glasnik/Military Technical Courier, 68(2), pp.216-224. Available at: https://doi.org/10.5937/vojtehg68-25948.

Fabiano, N. \& Radenović, S.N. 2020b. What could happen after the first wave of COVID-19 diffusion in Italy: learning from the 1918 influenza pandemic. Vojnotehnički glasnik/Military Technical Courier, 68(3), pp.413-423. Available at: https://doi.org/10.5937/vojtehg68-26500.

Fabiano, N. \& Radenović, S.N., 2021. The second COVID-19 wave of 2020 in Italy: A brief analysis. Vojnotehnički glasnik/ Military Technical Courier, 69(1), pp.1-7. Available at: https://doi.org/10.5937/vojtehg69-29511.

Henderson, D., Woodcock, H., Mehta, J., Khan, N., Shivji, V., Richardson, C., Aya, H., Ziser, S., Pollara, G. \& Burns, A. 2020. Keep calm and carry on learning: using Microsoft Teams to deliver a medical education programme during the COVID-19 pandemic. Future Healthcare Journal, 7(3), pp.67-70. Available at: https://doi.org/10.7861/fhj.2020-0071.

Jenkins, N.S. 2020. Connect Web Services to Microsoft Teams with Webhooks. In: Building Solutions with Microsoft Teams. Apress, Berkeley, CA. Available at: https://doi.org/10.1007/978-1-4842-6476-8_7.

Juan, S. 2021. Promoting engagement of nursing students in online learning: Use of the student-generated question in a nursing leadership course. Nurse Education Today, 97(art.number:104710). Available at: https://doi.org/10.1016/j.nedt.2020.104710.

Martin, L. \& Tapp, D. 2019. Teaching with Teams: An introduction to teaching an undergraduate law module using Microsoft Teams. Innovative Practice in Higher Education, 3(3) [online]. Available at: http://journals.staffs.ac.uk/index.php/ipihe/article/view/188 [Accessed: 28 September 2021].

Misha, L., Gupta, T. \& Shree, A. 2020. Online teaching-learning in higher education during lockdown period of COVID-19 pandemic. International Journal of Educational Research Open, 1(art.number:100012). Available at: https://doi.org/10.1016/j.ijedro.2020.100012.

Pal, D. \& Vanijja, V. 2020. Perceived usability evaluation of Microsoft Teams as an online learning platform during COVID-19 using system usability scale and technology acceptance model in India. Children and Youth Services Review, 119(art.number:105535). https://doi.org/10.1016/j.childyouth.2020.105535.

Available at: 
Pokorni, S. 2009. Distance education. Vojnotehnički glasnik/Military Technical Courier, 57(2), pp.138-146. Available at: https://doi.org/10.5937/vojtehg0902138P.

Purcarea, T.V. \& Purcarea, A. 2008. Distribution in Romania at the shelf supremacy's moment of truth: competition and cooperation. Amfiteatru Economic, 10(24), pp.9-25 [online]. Available at: https://www.amfiteatrueconomic.ro/ArticolEN.aspx?CodArticol=11 [Accessed: 28 September 2021].

Stevens, G. 2020. Teaching in the Post Covid Classroom: Mindsets and Strategies to Cultivate Connection, Manage Behavior and Reduce Overwhelm in Classroom, Distance and Blended Learning. New York: Red Lotus Books. Available at: https://www.barnesandnoble.com/w/teaching-in-the-post-covidclassroom-grace-stevens/1137550957 [online]. [Accessed: 28 September 2021]. ISBN: 0998701963.

Tsai, P. 2018. Business Chat Apps in 2018: Top Players and Adoption Plans. Spiceworks [online]. Available at: https://community.spiceworks.com/blog/3157-business-chat-apps-in-2018-topplayers-and-adoption-plans [online]. [Accessed: 28 September 2021].

Tucker, C.R. 2020. Balance with Blended Learning: Partner with Your Students to Reimagine Learning and Reclaim Your Life. Thousand Oaks, CA: Corwin Press [online]. Available at: https://books.google.com/books/about/Balance_With_Blended_Learning.html?id $=\mathrm{kHjEDwAAQBAJ}$ [online]. [Accessed: 28 September 2021]. ISBN: 9781544389523.

Tucker, C.R., Wycoff, T. \& Green, J.T. 2016. Blended Learning in Action: A Practical Guide Toward Sustainable Change. Thousand Oaks, CA: Corwin Press [online]. Available at: https://books.google.rs/books/about/Blended_Learning_in_Action.html?id=Ybj3D AAAQBAJ\&source $=\mathrm{kp} \_$book_description\&redir_esc $=y$ [online]. [Accessed: 28 September 2021]. ISBN: 978-1-5063-4116-3.

Van Rousselt, R. 2021. Pro Microsoft Teams Development. Springer. Available at: https://www.springer.com/de/book/9781484263631 [online]. [Accessed: 28 September 2021]. ISBN: 978-1-4842-6364-8.

ПОДХОД К ОБУЧЕНИЮ В ОСЛОЖНЕННЫХ УСЛОВИЯХ ПЕРЕДАЧИ ЗНАНИЙ ВСЛЕДСТВИЕ ЧРЕЗВЫЧАЙНОЙ СИТУАЦИИ, ВЫЗВАННОЙ ПАНДЕМИЕЙ

Милош М. Мравика ${ }^{\mathrm{a}}$ корреспондент, Марко К. Шараца, Младен Д. Веиновича, Нуно Г. Помбоб

а Университет Сингидунум, г. Белград, Республика Сербия

${ }^{\sigma}$ Внутренний университет Бейры, г. Ковильян, Португалия 
РУБРИКА ГРНТИ: 20.00.00 ИНФОРМАТИКА:

20.23.25 Информационные системы с базами,

12.00.00 НАУКОВЕДЕНИЕ:

12.21.35 Наука, культура и образование

ВИД СТАТЬИ: оригинальная научная статья

Резюме:

Введение/цель: В данной статье представлена трансформация существующего классического подхода к обучению. Онлайн-платформа позволяет всем студентам, в том числе $u$ студентам $c$ ограниченными возможностями беспрепятственно посещать лекции и занятия. После лекций они могут просмотреть видеозапись и презентационные материалы. Основным преимуществом такого способа обучения является возможность посещать занятия, находясь в любой точке с помощью любого устройства, единственным условием является наличие Интернета.

Методы: Произведена полная интеграция с уже существующей информационной системой фракультета. В статье описан новый подход к обучению и приведены ожидаемые преимущества онлайнобучения. Приведем платформы, используемые в данной интеграции: Microsoft Azure, Microsoft Office 365 Admin, Microsoft Teams, Microsoft Stream u Microsoft SharePoint.

Результаты: Результаты тестирования работы со студентами показали, что внедренная система онлайн-обучения имеет непосредственное влияние на улучшение качество обучения.

Выводы: Учитывая все результаты, можно сделать вывод, что онлайн-обучение позволяет конечным слушателям полноценно усвачвать знания во время лекций, а также они имееют возможность их повторного прослушивания.

Данной моделью может пользоваться неограниченное количество пользователей из всех учреждений, независимо от того, относится ли сфрера деятельности этих учреждений к системе образования.

Ключевые слова: образование, онлайн-обучение, анализ обучения, Microsoft Teams, Microsoft Azure.

ПРИСТУП НАСТАВИ У УСЛОВИМА ОТЕЖАНОГ ПРЕНОСА ЗНАЊА УСЛЕД ВАНРЕДНОГ СТАЊА ИЗАЗВАНОГ ПОЈАВОМ ПАНДЕМИЈЕ

Милош М. Мравика , аутор за преписку, Марко К. Шарац Младен Ђ. Веиновић ${ }^{\text {, Нуно Г. Помбо }}$

а Универзитет Сингидунум, Београд, Република Србија

${ }^{\sigma}$ Universidade da Beira Interior, Ковиља, Португал 
ОБЛАСТ: информационе технологије ВРСТА ЧЛАНКА: оригинални научни рад

\section{Сажетак:}

Увод/циљ: У овом раду приказана је трансформација тренутног, класичног приступа настави. Онлајн платфрорма омогућава свим студентима, па и оним са хендикепом, да несметано прате наставу у термину предавања. Након тога, омогућено им је да прегледају видео и презентационе материјале. Главна предност оваквог начина предавања јесте могућност присуствовања настави са било које локације и са било ког уређајакоји је повезан на интернет конекцију.

Методе: Извршена је потпуна интеграција са већ постојећим фракултетским информационим системом. Рад описује нови приступ настави и илуструје очекиване предности онлајн наставе. Платформе које су коришћене у овој интеграцији су: Microsoft Azure, Microsoft Office 365 Admin, Microsoft Teams, Microsoft Stream u Microsoft SharePoint.

Резултати: Резултат тестирања рада са студентима показао је да се увођењем система за онлајн реализацију наставе директно утиче на побољшање и квалитет наставе.

Закључак: Сагледајући све резултате може се доћи до закључка да прелазак на онлајн начин предавања омогућава крајњим слушаоцима свеобухватни пренос знања, као и његово поновно преслушавање. Овај модел је могуће користити на неограниченом броју корисника у свим институцијама, без обзира на њихову делатност.

Кључне речи: едукација, онлајн учење, анализа наставе, Microsoft Teams, Microsoft Azure.

Paper received on / Дата получения работы / Датум пријема чланка: 12.08.2021.

Manuscript corrections submitted on / Дата получения исправленной версии работы / Датум достављања исправки рукописа: 29.09.2021.

Paper accepted for publishing on / Дата окончательного согласования работы / Датум коначног прихватања чланка за објављивање: 30.09.2021.

(C) 2021 The Authors. Published by Vojnotehnički glasnik / Military Technical Courier (www.vtg.mod.gov.rs, втг.мо.упр.срб). This article is an open access article distributed under the terms and conditions of the Creative Commons Attribution license (http://creativecommons.org/licenses/by/3.0/rs/).

() 2021 Авторы. Опубликовано в «Военно-технический вестник / Vojnotehnički glasnik / Military Technical Courier» (www.vtg.mod.gov.rs, втг.мо.упр.срб). Данная статья в открытом доступе и распространяется в соответствии с лицензией «Creative Commons» (http://creativecommons.org/licenses/by/3.0/rs/).

() 2021 Аутори. Објавио Војнотехнички гласник / Vojnotehnički glasnik / Military Technical Courier (www.vtg.mod.gov.rs, втг.мо.упр.срб). Ово је чланак отвореног приступа и дистрибуира се у складу са Creative Commons licencom (http://creativecommons.org/licenses/by/3.0/rs/).

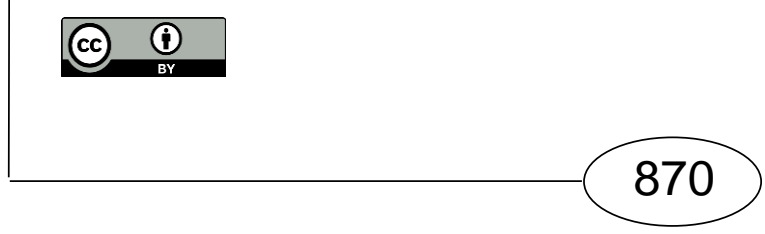

